\title{
Wkład Unii Europejskiej w rozwój międzynarodowego reżimu kosmicznego
}

Rosnące uzależnienie państw i społeczeństw od wykorzystania technologii kosmicznych skutkuje szybkim wzrostem aktywności w przestrzeni kosmicznej i pojawianiem się nowych podmiotów uczestniczących w jej eksploracji (w tym niepaństwowych). Generuje to także wiele negatywnych skutków czyniących środowisko kosmiczne coraz mniej bezpiecznym miejscem. Pojawiające się zagrożenia dotyczą zarówno stanu jego samego, jak i mają wpływ na bezpieczeństwo narodowe i międzynarodowe na ziemi. W efekcie narasta pilna potrzeba kolektywnego podejścia do sposobów zarządzania korzystaniem z przestrzeni kosmicznej. Rozwijający się od początku ery kosmicznej międzynarodowy reżim prawny dotyczący tego środowiska (kreowany głównie przez mocarstwa) nie jest już wystarczający, gdyż nie uwzględnia w wystarczającym stopniu szybko zachodzących zmian. Ponadto proces tworzenia prawa wymaga dhugiego czasu (wieloletnich negocjacji i procedur ratyfikacyjnych). Jedną z reakcji na widoczny impas w tej dziedzinie jest przygotowany przez Unię Europejską w 2008 r. projekt międzynarodowego Kodeksu Postępowania dotyczącego Działań w Przestrzeni Kosmicznej.

Celem niniejszego artykułu jest ukazanie problemów związanych z rozwojem międzynarodowego reżimu kosmicznego po zimnej wojnie na przykładzie losów Unijnej inicjatywy oraz ważniejszych przyczyn, dla których, mimo wieloletnich wysiłków i narastających problemów praktycznych, nadal nie udało się wypracować i przyjąc międzynarodowego kodeksu działań w przestrzeni kosmicznej. Artykuł został podzielony na cztery sekcje. Dwie pierwsze odnoszą się do reżimów międzynarodowych jako struktur globalnego zarządzania niezbędnych w dobie globalizacji szczególnie w odniesieniu do globalnych dóbr wspólnych, do których zalicza się przestrzeń kosmiczną. Sekcja trzecia ukazuje rozwój międzynarodowego reżimu kosmicznego i związane z nim dylematy; w ostatniej sekcji skupiono się na analizie i ocenie Unijnego projektu międzynarodowego Kodeksu Postępowania dotyczącego Działań w Przestrzeni Kosmicznej.

\section{Reżimy międzynarodowe}

Reżimy międzynarodowe to mechanizmy globalnego rządzenia/zarządzania (Nevers de, 1999), będące m.in. reakcją na różnorodne wyzwania, wobec których stoją państwa w warunkach globalizacji oraz na nasilające się współzależności i ich odczuwanie w stosunkach międzynarodowych. Reżimy to porozumienia (zobowiązania) oparte na normach i zasadach podzielanych przez państwa w anarchicznym środowisku między- 
narodowym. Na poziomie międzynarodowym reżimy są zwykle ucieleśnione w konwencjach, wielostronnych traktatach wiążących ich strony i nakładających na nie określone zobowiązania (Nevers de, 1999, s. 4), choć mogą też istnieć reżimy mające mniej formalną postać (np. deklaracji). Celem tych porozumień jest bardziej efektywne wykorzystywanie pojawiających się nowych możliwości naukowo-technicznych, a zarazem minimalizowanie niepożądanych konsekwencji ich wykorzystywania (zarówno przez państwa, jak i niepaństwowe podmioty, w tym struktury kryminalne) (Ozgercin, Weiss, 2009, s. 137-155).

Nie istnieje jedna, powszechnie akceptowana, definicja reżimu międzynarodowego (Levy, Young, Zürn, 1995, s. 267-330). Najczęściej przywoływana (i zarazem krytykowana), jest klasyczna definicja sformułowana przez Stephena Krasnera w 1983 r., która określa reżim międzynarodowy jako „zbiór formalnie lub nieformalnie wyrażonych zasad, norm, reguł i procedur decyzyjnych, wokół których zbiegają się oczekiwania aktorów w danym obszarze zagadnień" (Krasner, 1983, s. 2). Wspólne dla większości definicji reżimów jest to, że traktują one reżimy jak instytucje społeczne (w sensie formułowania stabilnego zbioru reguł, ról, relacji), będące produktem powtarzalności zachowań wielu jednostek i grup, które organizują działania zainteresowanych podmiotów w skonkretyzowanym obszarze zagadnień (March, Olsen, 2005). Reguły to nakazy i zakazy dotyczace określonych działań i zachowań aktorów; są najbardziej konkretnym ze składników reżimu, stoją poniżej zasad i norm. Reżim można uznać za silny, gdy jego reguly są szczelne, wyraźnie określone i dotyczą szerokiego zakresu działalności. Procedury to powszechne praktyki (mechanizmy) podejmowania i realizowania zbiorowych decyzji (Bryła, 2006, s. 18-21).

Na proces powstawania reżimu składają się trzy etapy: formułowanie agendy, decyzje instytucjonalne, operacjonalizacja. Faza formułowania agendy obejmuje zaistnienie kwestii na agendzie politycznej, przygotowanie jej do postawienia na forum międzynarodowym, a następnie nadanie jej wystarczająco wysokiej rangi, by na agendzie międzynarodowej zyskała priorytetowe miejsce. Faza wyborów instytucjonalnych rozciaga się między nadaniem kwestii priorytetowego znaczenia w agendzie międzynarodowej a osiagnięciem porozumienia, co do przepisów powstającego reżimu. Operacjonalizacja obejmuje działalność niezbędną dla przekształcenia porozumienia istniejącego na papierze w funkcjonującą praktykę społeczną. W stosunkach międzynarodowych faza operacjonalizacji obejmuje także wysiłki państw-stron, aby również aktorzy niepaństwowi działający pod ich jurysdykcją stosowali się do zasad reżimu (np. prywatni operatorzy kosmiczni). W niektórych przypadkach proces operacjonalizacji obejmuje kreowanie organizacji zajmujących się implementacją procedur przeglądowych.

Wyróżniającą cechą wszystkich instytucji społecznych, w tym reżimów międzynarodowych, jest połączenie zbieżności oczekiwań i praktyki, które jednak nie muszą wystapić równocześnie. Pojawienie się regularności, powtarzalności zachowań, reguł i zasad może sprzyjać zbieżności oczekiwań i odwrotnie - wzajemne zasilanie się tych elementów wpływa na rozwój i utrzymanie wielu społecznych instytucji (Young, 1982, s. 280). Zbieżności przyczyniają się do zachowań opartych na uznawanych społecznych konwencjach, gdyż są to wskazówki do działania, które aktorzy traktująjako obowiązujące bez konieczności analizowania każdego przypadku odrębnie. Dzięki temu 
reżimy pomagają przezwyciężać problemy koordynacji między podmiotami uczestniczącymi.

W kategoriach formalnych uczestnikami reżimów międzynarodowych są suwerenne państwa, choć stronami realizującymi działania regulowane przez reżimy międzynarodowe są też osoby prawne (np. kompanie połowowe, banki, prywatne linie lotnicze). W większości są to działania należące do jednej z trzech kategorii: 1) pozostające całkowicie poza jurysdykcją poszczególnych suwerennych państw (np. górnictwo podmorskie); 2) znajdujące się na pograniczu różnych sfer międzynarodowej jurysdykcji (np. połowy na pełnym morzu); 3) mające bezpośredni wpływ na interesy dwóch lub więcej członków społeczności międzynarodowej (np. warunki wymiany handlowej) (Keohane, Nye, 1977, s. 24-25).

Reżimy ograniczają zachowania państw do zbioru tych akceptowalnych i stąd redukują niepewność we wzajemnych relacjach. W interesie państw należących do reżimów leży przyłączanie do nich kolejnych uczestników przyjmujących na siebie określone zobowiązania (stąd dążenie do nadania istniejącym reżimom jak najszerszego zakresu podmiotowego, aż po uniwersalny). Również badanie wszelkich naruszeń zasad jest łatwiejsze w ramach reżimu, dzięki niemu wiadomo bowiem, kto i jakie zasady naruszył.

W zależności od sposobu powstania wyróżnia się reżimy spontaniczne, wynegocjowane i narzucone. Reżimy narzucone są ustanawiane i rozmyślnie podtrzymywane przez dominujących aktorów (mocarstwa), którzy dzięki kombinacji przymusu, kooptacji i manipulowania bodźcami skłaniają innych do podporządkowania się wymogom tych reżimów. Nierzadko reżimy te skutecznie funkcjonują mimo braku wyraźnego przyzwolenia ze strony podmiotów im podporządkowanych oraz braku sformalizowania. Istnieją dwa typy narzuconych reżimów: a) hegemonia (gdy dominujący aktor otwarcie narzuca powiązania instytucjonalne i zmusza podporządkowanych aktorów, by stosowali się do nich, np. feudalna zależność oraz systemy imperialne); b) narzucone de facto, gdy dominujący aktor może promować powiązania instytucjonalne korzystne dla siebie poprzez różne formy sprawowania przywództwa i manipulowanie zachętami. Dominujący podmiot nie musi stale przymuszać innych aktorów do przestrzegania zasad narzuconego reżimu (wystarczą nawyki posłuszeństwa), dlatego większość narzuconych reżimów nie opiera się na stałym wywieraniu jawnego przymusu.

Istotne jest też rozróżnienie między reżimami powszechnymi a częściowymi. Reżimy powszechne (np. konwencja o prawie morza) zwykle są rezultatem systematycznych negocjacji. Jednak konflikty interesów między uczestnikami wynegocjowanych reżimów powszechnych powodują, że mają one często fragmentaryczny charakter i pozostawiają wiele nierozwiązanych problemów do rozstrzygnięcia na bazie praktyki i precedensów.

Reżimy międzynarodowe nie są też statycznymi konstrukcjami - podlegają transformacjom zarówno pod wpływem własnej wewnętrznej dynamiki, jak i zmian zachodzących w ich otoczeniu. Szczególnie dynamiczne zmiany dokonują się współcześnie w sposobach dystrybucji najnowszych technologii. Np. szybki rozwój technologii satelitarnej wymusił zmiany we wcześniejszych porozumieniach międzynarodowych o wykorzystaniu fal radiowych i sposobach przydzielania częstotliwości. Fundamentalne zmiany w jednym reżimie międzynarodowym często rodzą nacisk na zmiany w innych. Gdy nasilają się wyzwania wobec status quo, utrzymanie go zaczyna wymagać bar- 
dziej formalnych rozwiązań, dlatego z czasem reżimy ulegają sformalizowaniu niezbędnemu dla podtrzymania ustalonych norm i procedur.

\section{Globalne dobra wspólne}

Prawo międzynarodowe rozróżnia takie globalne dobra wspólne, jak: morze otwarte (pełne), atmosfera, Antarktyka oraz przestrzeń kosmiczna. Nadanie im takiego statusu, a następnie 'gospodarowanie' nimi, nie byłoby możliwe bez globalnego zarządzania (Global governance, 2013, s. 5). Przestrzeń kosmiczna została uznana za globalne dobro wspólne niepodlegające zawłaszczeniu na podstawie Traktatu z 1967 r. (Laver, 1986, s. 359-373). Globalne dobra wspólne to rodzaj globalnych dóbr publicznych (m.in. dobra wspólnej puli), czyli dóbr pozostających poza wyłączną kontrolą któregokolwiek z państw, niepodlegających niczyjej suwerennej jurysdykcji, niewyznaczanych przez terytorialne granice (Hacket, 1994, s. 61). Do cech charakterystycznych globalnych wspólnych dóbr należą: otwarty dostęp, niewykluczalny charakter i wspólna pula zasobów, które nie mogą zostać zawłaszczone przez użytkowników (Vogler, 1995, s. 2). Legalny dostęp do nich mają zarówno wszystkie państwa, jak i podmioty niepaństwowe (Hardin, 1968, 1992, s. 1243-1248). Niewykluczalność dóbr to niemożność pozbawienia innych państw (podmiotów) możliwości korzystania z nich (po racjonalnych kosztach) (Keohane, Victor, 2010, s. 10). Jednak już zasoby znajdujące się $\mathrm{w}$ tych środowiskach stanowią kombinację dóbr rywalizacyjnych ${ }^{1}$ i nie-rywalizacyjnych (Bryła, 2013, s. 14). Na przykład orbita geostacjonarna (część przestrzeni kosmicznej) ma w swej istocie charakter rywalizacyjny - jest to zasób „podlegający zatłoczeniu [...], ale teoretycznie dostępny dla wszystkich" (Kaul, Grunberg, Stern, 1999, s. 5).

Zasoby to obiekty, do których odnosi się koncepcja własności. Można je pojmować jako ,wszystko, co jest wykorzystywane do zaspokojenia potrzeb organizmu” (Mason, 2004, s. 19). Są to zarówno zasoby naturalne, jak i tzw. spatial-extension resources. Zasoby naturalne to 'materiały', które mają wartość pozyskane w ich naturalnym stanie, $\mathrm{np}$. ryby wyłowione z oceanu, rudy metali wydobyte z ziemi lub informacja genetyczna pochodząca z żywych organizmów; dzielą się na odnawialne i nieodnawialne; z kolei spatial-extension resources to zasoby, których wartość zależy od ich lokalizacji (umiejscowienia) i jest z nią związana, niezależnie od tego, czy można je „wydobyć” i przetworzyć (Buck, 2013, s. 239). Innymi słowy, to cechy samego środowiska, w którym znajdują się zasoby, określają czy są to dobra wspólne, na przykład orbita geostacjonarna (część przestrzeni kosmicznej), z której równocześnie może korzystać tylko ograniczona (skończona) liczba satelitów (Mason, 2004, s. 19). W 1973 r. Międzynarodowy Związek Telekomunikacyjny uznał częstotliwości radiowe i orbitę geostacjonarną za ograniczone zasoby naturalne, które muszą być wykorzystywane efektywnie i ekonomicznie.

1 Rywalizacyjny charakter dobra oznacza, że konsumpcja danego dobra przez jeden podmiot pozbawia innych możliwości identycznego wykorzystania walorów tego dobra dla własnych korzyści. 
Globalne dobra wspólne są, ,uznane za ważne dla społeczności międzynarodowej. Poszczególne państwa nie mogą lub nie zajmą się nimi odpowiednio, więc należałoby troszczyć się o nie wielostronnie i zbiorowo" (Task Force on Global Public Goods). Nieuregulowany dostęp do dóbr wspólnych może skutkować stratami w zasobach tego dobra i długofalowo ograniczyć korzyści wszystkich jego użytkowników. Dlatego niezbędne jest określenie form kontroli oraz zasad dostępu i wykorzystania wspólnych zasobów w nich zawartych (Einstein, 1999, s. 59-98). Aby kontrola ta była skuteczna konieczne jest poczucie wspólnoty (Mason, 2004, s. 20).

\section{Międzynarodowy reżim kosmiczny}

Wraz z początkiem ery kosmicznej, zainicjowanej umieszczeniem na orbicie okołoziemskiej pierwszego sztucznego satelity, należało przyjąć uzgodnienia dotyczące sposobów korzystania $\mathrm{z}$ dostępu do nowego środowiska. $Z$ wielu powodów nie było to łatwe zważywszy, że równocześnie trwała zimna wojna i zacięta rywalizacja amerykańsko-radziecka. Mimo to zdołano wypracować podstawowe zasady dotyczące aktywności w kosmosie.

Powszechne prawo międzynarodowe nie jest wystarczające dla efektywnego zarządzania eksploracją i wykorzystaniem przestrzeni kosmicznej, gdyż nie uwzględnia specyficznych cech poszczególnych globalnych wspólnych dóbr, co jest szczególnie odczuwalne w przypadku przestrzeni kosmicznej - prawo skupia się na państwach jako głównych podmiotach i na ziemskich podziałach będących konsekwencją zasady suwerenności i terytorialności. Przezwyciężeniu tych ograniczeń służą zasady i normy międzynarodowego prawa kosmicznego, rozwijanego dotychczas głównie w ramach Komitetu Narodów Zjednoczonych ds. Pokojowego Wykorzystania Przestrzeni Kosmicznej (UNCOPUOS). Nieformalnym składnikiem prawa międzynarodowego są reżimy międzynarodowe.

Międzynarodowy reżim kosmiczny, to ksztaltujący się reżim prawny odnoszący się do globalnego wspólnego dobra, za które uznano przestrzeń kosmiczną. Możliwości i problemy związane z każdym z obszarów uznawanych przez społeczność międzynarodową za wspólne dobro (Antarktyka, morze otwarte oraz przestrzeń kosmiczna łącznie z Księżycem i innymi ciałami niebieskimi, atmosfera) nie są identyczne, więc nie zdecydowano się na podjęcie działań, aby ustanowić jeden reżim prawny, który dotyczyłby ich wszystkich. Istniejące między tymi dobrami różnice nie pozwalają też na automatyczne przenoszenie i stosowanie rozwiązań odnoszących się do jednego specyficznego obszaru - na inne. Dlatego zamiast jednego - rozwijane są odrębne systemy prawne dla każdego z tych środowisk.

Początkowe wysiłki związane z tworzeniem zalążków reżimu kosmicznego (najmłodszego spośród reżimów dotyczących wspólnych dóbr) skupiały się wokół trzech istniejących analogii: analogii do przestrzeni powietrznej, do morza otwartego oraz do Antarktyki (Tannenwald, 2003, s. 9-10).

Analogia do przestrzeni powietrznej opiera się na przekonaniu o suwerennym prawie każdego państwa do kontrolowania wszelkiej działalności w obrębie własnego terytorium, którego częścią jest przestrzeń powietrzna. Na tej podstawie zakłada się, że 
zasady dotyczące działalności wojskowej, które obowiązują wewnątrz państwa, w tym w jego przestrzeni powietrznej, należy stosować również do przestrzeni kosmicznej. Reguły te obejmuja prawo do utrzymywania i rozwoju środków zbrojnych oraz ich użycia w samoobronie, tj. np. prawo zestrzelenia samolotu, który bez zezwolenia naruszy przestrzeń powietrzną.

Analogia do morza otwartego (pełnego), wiąże się z traktowaniem przestrzeni kosmicznej jak „wspólnego dobra” - obszaru, z którego wolno korzystać wszystkim państwom, także w celach wojskowych, o ile działania te są zgodne z prawem międzynarodowym. Np. wysłanie okrętów wojennych na pełne morze jest dozwolone, a ograniczenia z nim związane wynikaja jedynie z ogólnych zasad Karty Narodów Zjednoczonych, które regulują kwestie użycia siły między państwami.

Analogia do Antarktyki, pojawiła się po zawarciu Traktatu Antarktycznego w 1959 roku, skutkującego m.in. demilitaryzacją (i denuklearyzacja) tego obszaru. Traktat stanowi, że Antarktyka będzie wykorzystywana wyłącznie „do celów pokojowych”, i definiuje to jako zakaz wszelkiej aktywności wojskowej. Wynikają z niego dalej idące ograniczenia niż te, które obowiązują w granicach państwa lub na morzu otwartym (np. w działaniach wojskowych uznawanych przez KNZ za defensywne).

Każda z powyższych analogii nakazuje odmienne podejście do uregulowania kwestii przestrzeni kosmicznej. Analogia do przestrzeni powietrznej i morza otwartego każe traktować przestrzeń kosmiczną jako otwartą na różne formy aktywności wojskowej dopuszczalne $\mathrm{w}$ ramach powszechnego prawa międzynarodowego, a analogia do Antarktyki sugerowałaby zakazanie w przestrzeni kosmicznej wszelkiej działalności wojskowej.

Istotną rolę w rozwoju prawa kosmicznego odegrał wspomniany wyżej stały Komitet NZ ds. Pokojowego Wykorzystania Przestrzeni Kosmicznej (UNCOPUOS). Jest to działający od 1959 r. organ pomocniczy Zgromadzenia Ogólnego ONZ początkowo złożony z 24 państw (obecnie 77). Do jego zadań należy zarządzanie sprawami związanymi z aktywnością w kosmosie oraz rozwój regulującego ją prawa. Szczególne zasługi ma Podkomitet Prawny UNCOPUOS, który przygotował projekty najważniejszych umów oraz wielu deklaracji i rezolucji dotyczących prawa kosmicznego. M.in. na XVIII sesji Zgromadzenia Ogólnego ONZ (13 grudnia 1963 roku) przyjęto „Deklarację zasad prawnych rządzących działalnością państw w zakresie badania i wykorzystywania przestrzeni kosmicznej", które następnie potwierdzono i rozwinięto w sześciu wielostronnych traktatach (Bryła, 2015, s. 8-9). Sa to:

1. Układ o zasadach działalności państw w zakresie badań i użytkowania przestrzeni kosmicznej, łącznie z Księżycem i innymi ciałami niebieskimi z 27 stycznia 1967 r., sporządzony w Moskwie, Londynie i Waszyngtonie (nazywany w skrócie Traktatem o Przestrzeni Kosmicznej);

2. Umowa o ratowaniu kosmonautów, powrocie kosmonautów i zwrocie obiektów wypuszczonych w przestrzeń kosmiczną z 22 kwietnia 1968 r., sporządzona w Moskwie, Londynie i Waszyngtonie;

3. Konwencja o międzynarodowej odpowiedzialności za szkody wyrządzone przez obiekty kosmiczne z 29 marca 1972 r., sporządzona w Moskwie, Londynie i Waszyngtonie (Dz. U. 1973, Nr 27, poz. 154);

4. Konwencja o rejestracji obiektów wypuszczonych w przestrzeń kosmiczną z 14 stycznia 1975 r., sporządzona w Nowym Jorku (Dz. U. 1979, Nr 5, poz. 22); 
5. Konwencja o przekazywaniu i wykorzystywaniu danych ze zdalnego badania Ziemi z kosmosu z 1978 r. (Dz. U. 1980, Nr 10, poz. 27 - załącznik);

6. Układ normujący działalność państw na Księżycu i innych ciałach niebieskich z 18 grudnia 1979 r., sporządzony w Nowym Jorku.

Na reżim kosmiczny składają się też te spośród traktatów o kontroli zbrojeń, które częściowo odnoszą się do przestrzeni kosmicznej, wśród nich:

1) Traktat o Częściowym Zakazie Prób z Bronią Jądrową (1963) zakazujący przeprowadzania prób jądrowych w atmosferze, przestrzeni kosmicznej i pod wodą (Dz. U. 1963, Nr 52 poz. 288);

2) traktat ABM z 1972 r., który do czasu wygaśnięcia (13 VI 2002 r.) zakazywał supermocarstwom rozbudowy kosmicznych systemów obrony rakietowej.

Zarówno SALT I, jak i SALT II, mimo że głównie dotyczyły kontroli wyrzutni na lądzie i na okrętach podwodnych, zawierały też zapisy dotyczące przestrzeni kosmicznej. SALT I (razem z Traktatem ABM) zakazywał ingerowania w narodowe techniczne środki weryfikacji, np. satelity (Interim Agrement..., 1972). Traktat SALT II zakazywał rozwijania, testowania i wykorzystania BMZ w kosmosie (Treaty Between..., 1972). Ponadto reżim prawny przestrzeni kosmicznej obejmuje też umowy regulujące komercyjne wykorzystanie przestrzeni kosmicznej, takie jak prawo do korzystania z orbity geostacjonarnej, umowy ustanawiające organizacje międzyrządowe (na przykład Umowa Międzyrządowa o Międzynarodowej Stacji Kosmicznej, Międzynarodowej Unii Telekomunikacyjnej, Międzynarodowej Organizacji Lotnictwa Cywilnego i Światowej Organizacji Meteorologicznej) i in.

Fundamentalne znaczenie dla reżimu prawnego przestrzeni kosmicznej ma Traktat o Przestrzeni Kosmicznej zawarty w 1967 r. (Outer Space Treaty, OST). Ustanowił on podstawy reżimu prawnego i dalszego rozwoju prawa kosmicznego. Jest najważniejszym aktem prawnym dotyczącym przestrzeni kosmicznej. Jako pierwszy traktat reguluje zagadnienia związane $\mathrm{z}$ dostępem (wolnym) do przestrzeni kosmicznej oraz podjął kwestię uzbrajania kosmosu. Przestrzeń kosmiczna została uznana za wspólne dziedzictwo ludzkości niepodlegające zawłaszczeniu w całości lub części (Art. II) (żadne państwo, organizacja ani jednostka nie może rościć sobie prawa własności do żadnego ciała niebieskiego, w tym planet i ich satelitów, komet lub asteroidów). Kosmos nie jest niczyją własnością (należy do wszystkich) w zamian za prawo równego dostępu do niego. Zgodnie z Traktatem przestrzeń kosmiczna ma być wykorzystywana do „celów pokojowych” (Art. IV), początkowo interpretowanych restrykcyjnie jako „,niewojskowe”. Wkrótce jednak praktyka obu supermocarstw spowodowała, że przez „pokojowe" zaczęto też rozumieć pasywne środki wojskowe, stąd "pokojowe' interpretowano jako ,nieagresywne”. Mimo że wiele państw rozwijających się jest przeciwnych takiej interpretacji i rozumie ,pokojowe” jako ,niewojskowe”, to żadne państwo nigdy oficjalnie nie zaprotestowało przeciwko interpretacji narzuconej przez mocarstwa, co byłoby niezbędne, aby niedopuścić do przekształcenia się tej zasady w normę prawa zwyczajowego (Vlasic, 1991, s. 38-42, 44-45).

Jednak ze względu na jak dotąd niewielką, choć stale rosnącą, liczbę państw zdolnych prowadzić działania w przestrzeni kosmicznej, nie było okazji, by przetestować większość powyższych zasad w praktyce, więc pozostają one głównie w sferze intencjonalnej. Póki co, sama definicja „celów pokojowych” jest kwestionowana jako nie- 
jasna, ochrona środowiska kosmicznego jest słaba, nie zdołano też uzgodnić, jak należy rozumieć użyte w Traktacie pojęcie „domena całej ludzkości” w odniesieniu do przestrzeni kosmicznej. Efektem jest m.in. coraz bardziej zauważalna przepaść między zasadą ,równego dostępu" do przestrzeni kosmicznej (intencjonalnie wyrażoną w OST), a stosowaną dotąd praktyką ,kto pierwszy, ten lepszy”. Z korzyści, jakie z tej praktyki wynikają, na pewno nie zrezygnują dotychczasowe mocarstwa kosmiczne. Widać to na przykładzie próby nałożenia pewnych ograniczeń na sposoby wykorzystywania przestrzeni kosmicznej i ciał niebieskich, zawartej w układzie dotyczącym działalności państw na Księżycu i innych ciałach niebieskich (Traktat Księżycowy, 1979), która spowodowała, że układ nigdy nie wszedł w życie. Zakładał on (Art. 11) powołanie odrębnego reżimu prawnego w stosunku do zasobów naturalnych Księżyca i ciał niebieskich Układu Słonecznego opartego na zasadzie wspólnego dziedzictwa ludzkości (Agreement Governing, 1979). Oznaczało to zagwarantowanie w przyszłości sprawiedliwego podziału, pomiędzy państwa-strony układu, korzyści, jakie będą przynosić te zasoby, ze szczególnym uwzględnieniem interesów i potrzeb państw rozwijających się.

Choć istniejący reżim kosmiczny formalnie ma charakter reżimu wynegocjowanego, to sposób jego powstawania wyraźnie wykazuje analogię do procesu tworzenia prawa dla innego globalnego dobra wspólnego - morza otwartego. Najpierw powstał reżim spontaniczny oparty na niepisanych zasadach, a następnie na normach zwyczajowych (McDougal, 1963, s. 618-642) wykreowanych przez mocarstwa, które jako pierwsze zaczęły podbój kosmosu (Young, 1982, s. 277-297) i w dalszej kolejności narzuciły te normy innym państwom za ich milczącą zgodą (wobec braku możliwości efektywnego sprzeciwu). Od początku ery kosmicznej największy wpływ na rozwój międzynarodowego prawa regulującego działalność w kosmosie miały państwa (mocarstwa) kosmiczne. Fundamenty obecnego reżimu prawnego dla przestrzeni kosmicznej powstawały w czasie, gdy dwa supermocarstwa praktycznie posiadały monopol na dostęp do niej. Po zimnej wojnie sytuacja uległa zmianie i obecnie wśród interesariuszy są też rządy nowych państw kosmicznych, aktorzy prywatni oraz państwa w żaden sposób niepartycypujące w programach kosmicznych ${ }^{2}$. Nowa grupa szybko rozwijających się państw, prywatne przedsiębiorstwa, a nawet jednostki uzyskują dostęp zarówno do przestrzeni kosmicznej, jak i usług świadczonych za jej pośrednictwem. Wzajemna zależność państw korzystających z, i zależnych od, technologii kosmicznych oraz nasilająca się aktywność w kosmosie sprawiają że rośnie odczuwalna przez wszystkich wrażliwość na ewentualne zniszczenia (uszkodzenia) elementów infrastruktury kosmicznej. Dlatego w interesie wszystkich leży uzgodnienie zasad postępowania regulujących aktywność $w$ tym środowisku, które uwzględniałyby nowe wyzwania, a więc i rozwój reżimów promujących pożądane modele zachowań.

2 Państwa rozwijające się, świadome politycznej i ekonomicznej wartości dostępu do przestrzeni kosmicznej, na długo przed uzyskaniem technicznych możliwości w tym kierunku zabiegały o zagwarantowanie sobie miejsc na orbitach geostacjonarnych i spectrum radiowym, aby móc je "dzierżawić" lub wykorzystać jako kartę przetargową w negocjacjach, do czasu, gdy rozwiną techniczne możliwości korzystania z nich. W 1979 r. Międzynarodowy Związek Telekomunikacyjny przydzieli1 państwom rozwijającym się częstotliwości umożliwiające satelitarną lączność radiową (chociaż nie byly w stanie z niej korzystać) oraz miejsca na orbitach dla satelitów (których nie posiadaly) (Buck, 2012, s. 157). 
Tymczasem w procesie tworzenia prawa kosmicznego na forum ONZ widoczny jest kryzys. UNCOPUOS musi zatwierdzić każdy uzgodniony tekst w drodze consensusu, a następnie przesłać go Zgromadzeniu Ogólnemu ONZ. W ostatnich latach uzyskanie consensusu staje się coraz trudniejsze, a brak wielostronnej współpracy zagroził podstawowym zasadom i przyszłemu rozwojowi prawa kosmicznego. W rezultacie państwa zaczęły rezygnować z tworzenia prawa tą drogą na rzecz policentrycznego zarządzania i podejścia oddolnego uwzględniającego narodowe plany działania, instrumenty dwustronne oraz porozumienia regionalne. W zarządzaniu przestrzenią kosmiczną widoczne jest odchodzenie od 'złotej ery' tworzenia prawa kosmicznego przez wąską grupę mocarstw kosmicznych na rzecz policentrycznego zarządzania, w którym państwa nie są już jedynym źródłem prawa (Shackelford, 2014, s. 5). Na rozwój reżimu kosmicznego w coraz większym stopniu ma zatem wpływ nie tylko szybko rosnąca ilość państw realizujących własne lub uczestniczących w programach kosmicznych, ale i wzrost udziału podmiotów sektora prywatnego w eksploracji kosmosu. Różnorodność zaangażowanych podmiotów i ich interesów w kosmosie skutkuje rozproszeniem zarządzania dostępem i wykorzystaniem przestrzeni kosmicznej charakterystycznym dla policentryzmu. Zarządzanie policentryczne zakłada w uproszczeniu system regulacyjny (czasem kompleks reżimów) (Orsini, Morin, Young, 2013), cechujący się istnieniem wielu władz, zamiast jednej monocentrycznej, działających na różną skalę (Ostrom, 2010, s. 550-557), oraz powiązania między konkretnymi, ale stosunkowo wąskimi reżimami, jednak bez całościowej struktury, która organizowałaby całość (Keohane, Victor, 2009, s. 4). W systemie policentrycznym, inaczej niż w monocentrycznym, państwo nie odgrywa centralnej roli (Black, 2008, s. 137-138). Szereg współzależnych interesariuszy z sektora publicznego i prywatnego wzajemnie na siebie oddziałując wypracowuje nowe reguły i zasady. Negocjowanie wielostronnych traktatów międzynarodowych jest długotrwałym procesem, podczas gdy tworzenie elastycznych, luźno powiązanych reżimów stanowi praktyczną odpowiedź na bieżące potrzeby i wyzwania, do których należy np. problem gruzu kosmicznego. Z czasem niektóre $z$ luźnych i nieformalnych praktyk, reguł i norm (standardów zachowania) mogą przekształcić się w skodyfikowany reżim. Taki sposób tworzenia prawa wiąże się też z pewnymi trudnościami, np. niespójnością prawną między poszczególnymi reżimami i zawartymi w nich regułami, co najlepiej widać na przykładzie reżimu kosmicznego, który coraz bardziej przypomina policentryczny kompleks, złożony z nakładających się, a czasem konkurencyjnych reżimów (Shackelford, 2014, s. 22). Jednak globalne zarządzanie wspólnymi dobrami pokazuje, że żaden pojedynczy rząd zwykle nie jest w stanie zarządzać problemem kolektywnego działania na skale globalną. Nie ma też gwarancji, że rozwiązania ,negocjowane na poziomie globalnym, jeśli nie są wspierane przez szereg działań na poziomie krajowym, regionalnym (Regional Perspectives on Norms of Behaviour, 2015) i lokalnym, będą dobrze działać" (Ostrom, 2008).

Istniejący obecnie podstawowy katalog ogólnych zasad prawa kosmicznego (takich jak uznanie przestrzeni kosmicznej za dobro wspólne, wolność i niezawłaszczalność przestrzeni kosmicznej i ciał niebieskich, w tym prawo swobodnego dostępu do nich i ich użytkowania, wykorzystywanie przestrzeni kosmicznej do celów pokojowych, promowanie odpowiedzialności i współpracy w zakresie jej wykorzystania dla dobra 
wszystkich, oraz współpraca międzynarodowa i pomoc w tych działaniach), aczkolwiek ważny, jest już niewystarczający. Niektóre z powyższych zasad nadal nie doczekały się jednoznacznego zdefiniowania, ciagle brak też konkretnych wytycznych co do ich operacjonalizacji w praktyce, szczególnie w obszarze bezpieczeństwa. Nina Tannenwald postuluje w związku z tym, by stare analogie (np. wolność mórz), zastapić nowymi zasadami organizacyjnymi, jak powszechne bezpieczeństwo i równa ochrona w kosmosie. Pilna potrzeba dotyczy też efektywnych zbiorowych procesów decyzyjnych i mechanizmów monitorowania i egzekwowania przestrzegania przepisów. W proces negocjowania bardziej całościowego reżimu trzeba będzie zaangażować również podmioty niepaństwowe (Tannenwald, 2003, s. 43-44).

Spośród wielu różnych inicjatyw międzynarodowych dotyczących kształtowania norm postępowania w przestrzeni kosmicznej (Lukaszczyk, 2012) kilka zasługuje na szczególną uwagę. Są to:

1) wspólny chińsko-rosyjski projekt Traktatu o Zapobieganiu Umieszczania Broni w Przestrzeni Kosmicznej, Groźbie oraz Użyciu Siły wobec Obiektów Kosmicznych (PPWT);

2) długoterminowe zrównoważenie działań w przestrzeni kosmicznej, opracowywane przez grupę roboczą Komitetu ONZ ds. pokojowego wykorzystania Przestrzeni Kosmicznej (UNCOPUOS);

3) Projekt Kodeksu Postępowania dotyczącego Działań w Przestrzeni Kosmicznej przedłożony przez Unię Europejską.

$\mathrm{Z}$ uwagi na temat niniejszego opracowania skoncentruję się na ostatnim $\mathrm{z}$ wymienionych.

\section{Kodeks Postępowania dotyczący Dzialań w Przestrzeni Kosmicznej}

Jak wspomniano wyżej, w regulacjach prawnych dotyczących przestrzeni kosmicznej występują luki, a równocześnie narastają bardzo praktyczne wyzwania związane $\mathrm{z}$ nasilającymi się działaniami $\mathrm{w}$ kosmosie. Uzależnienie państw i społeczeństw od technologii kosmicznych czyni niezakłócony dostęp do przestrzeni kosmicznej, i świadczonych za jej pośrednictwem usług, kwestią żywotną dla bezpieczeństwa narodowego i międzynarodowego. Dlatego brak międzynarodowego konsensusu co do zasad odpowiedzialnego zachowania w przestrzeni kosmicznej stanowi, obok gruzu kosmicznego (Padget, 1996), zatłoczenia orbity geostacjonarnej i braku dostępnych częstotliwości operacyjnych dla satelitów, realne zagrożenie. Pilną potrzebą staje się uzgodnienie najlepszych praktyk postępowania w przestrzeni kosmicznej. Jedną z prób w tym kierunku jest Kodeks Postępowania dotyczący Działań w Przestrzeni Kosmicznej przygotowany przez Unię Europejska. Projekt Kodeksu został przyjęty przez Radę Unii Europejskiej 3 grudnia 2008 r. (warto wspomnieć, że przed 2007 r. bezpieczeństwo kosmiczne nie było istotną częścią polityki UE. Sytuacja zmieniła się w 2007 r. po przyjęciu przez UE Europejskiej Polityki Kosmicznej). Kodeks ma na celu ustanowienie dobrowolnych zasad postępowania dla państw (operatorów kosmicznych) wysyłających satelity $\mathrm{i}$ inne obiekty w przestrzeń kosmiczną, w zgodzie z zasadą jej pokojowego wykorzystania i zapewnienia równego dostępu wszystkim państwom. Ma to pomóc w rozwiązaniu 
problemu zatłoczenia przestrzeni okołoziemskiej i związanego z nim ryzyka kolizji. Dokument wymienia również środki służące minimalizowaniu ilości powstających odpadów kosmicznych. Kodeks jest otwarty dla wszystkich państw i oparty na dobrowolności - nie ma charakteru prawnie wiążącego. W założeniu projekt miał być podstawą dalszych konsultacji z głównymi państwami trzecimi prowadzącymi działania w przestrzeni kosmicznej, lub zainteresowanymi tymi działaniami, służącą wypracowaniu tekstu możliwego do zaakceptowania przez jak największą liczbę państw.

Propozycja UE nie była pierwszą tego rodzaju - w 2004 r. Centrum Stimsona opublikowało Modelowy Kodeks Postępowania dla Odpowiedzialnych Państw Kosmicznych (druga wersja pochodzi z 2007 r.) (Model Code Of Conduct, 2013). Jego głównym celem miało być zachowanie i rozwój pokojowych badań i wykorzystania przestrzeni kosmicznej. W tamtym czasie inicjatywa ta była wyjątkowa, ponieważ tworzyła kompleksowe ramy dla wszelkiej aktywności w przestrzeni kosmicznej. Intencją twórców Unijnego Kodeksu Postępowania również jest uregulowanie działalności w przestrzeni kosmicznej, dlatego dotyczy on zarówno wojskowych, jak i cywilnych aspektów jej wykorzystania. Ponieważ jednak projekt Unii Europejskiej pojawił się jako reakcja na impas w pracach Konferencji Rozbrojeniowej ONZ (Robinson, 2013), więc był postrzegany jako dotyczący wyłącznie, lub głównie, bezpieczeństwa kosmicznego, zamiast $w$ równym stopniu bezpieczeństwa w kosmosie, jak i bezpieczeństwa przestrzeni kosmicznej (jako środowiska) (Blount, 2012, s. 1-2). Nie bez znaczenia dla zainicjowania prac nad dokumentem był też chiński test ASAT przeprowadzony w $2007 \mathrm{r}$. (Bernhardsdotter, 2013, s. 81-86). Ze względu na duży nacisk, jaki położono w projekcie Kodeksu na Środki Przejrzystości i Budowy Zaufania w przestrzeni kosmicznej (TCBMs) (Transparency and Confidence-Building Measures, 2013) dokument był promowany jako instrument przewidywalności w aktywności kosmicznej (Robinson, 2012, s. 29).

Cesar Jaramillo dzieli zagrożenia związane z przestrzenią kosmiczną, które są skutkiem działalności człowieka, na dwie kategorie (Jaramillo, 2011): zagrożenia dla aktywów kosmicznych wynikające z ,normalnych” (rutynowych) pokojowych operacji w kosmosie (np. ryzyko zderzenia się satelitów, lub satelity czy statku kosmicznego z kawałkiem gruzu kosmicznego), oraz zagrożenia wynikające z militaryzacji i potencjalnego uzbrajania kosmosu. Unijny Kodeks odnosi się do tych pierwszych, służących unikaniu kolizji poprzez wspólne niezobowiązujące mechanizmy, takie jak dzielenie się danymi dotyczącymi położenia, przemieszczania się i działań obiektów kosmicznych, ponadto ,wcześniejsze zgłaszanie startów, ryzykownych manewrów, przewidywanych kolizji, rozpadu/rozbicia na orbicie i innych zniszczeń, awarii obiektów działających w kosmosie i zdarzeń wysokiego ryzyka przy powrocie". Inny mechanizm wymaga, by państwa dzieliły się informacjami na temat swoich krajowych strategii kosmicznych i polityk, programów badawczych i procedur w celu zapobiegania i zminimalizowania wypadków, kolizji i tworzenia gruzu kosmicznego, i czyniły wysiłki na rzecz przyjęcia przepisów kosmicznych i podobnych środków.

Zaprezentowanie projektu Kodeksu społeczności międzynarodowej było zarazem jedną $\mathrm{z}$ pierwszych prób skorzystania przez UE $\mathrm{z}$ nowych uprawnień $\mathrm{w}$ zakresie kształtowania wspólnej polityki zagranicznej i bezpieczeństwa określonych na mocy Traktatu lizbońskiego. Chociaż żadne państwo spoza Unii nie podpisało się pod projek- 
tem, zgodnie widziano $\mathrm{w}$ nim podstawę do negocjacji w sprawie międzynarodowego kodeksu postępowania w przestrzeni kosmicznej. W następstwie doszło do szeregu spotkań z udziałem zainteresowanych państw, podczas których skupiono się na tworzeniu dobrowolnego, niewiążącego kodeksu możliwego do przyjęcia przez jak największą liczbę państw.

Charakterystyczne jest, że większość zarzutów kierowanych pod adresem pierwszego projektu Kodeksu w mniejszym stopniu dotyczyła jego treści, niż samego sposobu, w jaki powstawał, tj. niewystarczających i mało przejrzystych konsultacji z państwami trzecimi (w ocenie ich samych). Dlatego w trakcie prac nad zmienionym projektem Unia Europejska zaangażowała się w szereg dwustronnych konsultacji m.in. z udziałem Brazylii, Kanady, Chin, Indii, Indonezji, Izraela, Rosji, USA, RPA, Korei Płd. Nowy projekt został przyjęty przez Radę Unii Europejskiej 27 września 2010 (Conclusions of the Council of the European Union, 2010). Uwzględniono w nim część uwag zgłoszonych w trakcie dwustronnych konsultacji z różnymi państwami. W porównaniu z wersją z 2008 r. widoczny jest wysiłek, by unikać sformułowań, które mogłyby rodzić obawy niektórych państw, że choć Kodeks w zamierzeniu ma być dokumentem miękkiego prawa, to w rzeczywistości jego projekt był pisany z myślą o (przyszłym) traktacie, który w dodatku jest zamaskowaną próbą kontroli zbrojeń. Jednak już reakcja samych mocarstw była mało obiecująca. Rosja stała na stanowisku, że taki kodeks należałoby wypracowywać na forum ONZ (Bernardsdotter, 2013, s. 85), a Chiny dodatkowo wolały pracować nad propozycją Traktatu o Zapobieganiu Umieszczania Broni w Przestrzeni Kosmicznej, Groźbie oraz Użyciu Siły wobec Obiektów Kosmicznych (PPWT) i sprzeciwiły się regulacjom dotyczącym kwestii kosmicznego gruzu. Za najlepsze rozwiązanie uważają przyjęcie prawnie wiążącego traktatu, który zapobiegłby uzbrajaniu przestrzeni kosmicznej i wyścigowi zbrojeń. Instrumenty „miękkiego prawa”, jak Unijny Kodeks, są przez Chiny postrzegane jako uzupełniające środki w dziedzinie kontroli zbrojeń kosmicznych. Stany Zjednoczone również odmówiły podpisania się pod projektem Kodeksu, ponieważ zakładał on m.in., że państwo zobowiązuje się powstrzymać od działań wojskowych w przestrzeni kosmicznej nawet gdyby samo stało się celem takich działań. Sekretarz stanu H. Clinton zapowiedziała, że Waszyngton „nie dołączy do kodeksu, który w jakimkolwiek stopniu ogranicza działania kosmiczne związane $\mathrm{z}$ bezpieczeństwem narodowym, lub działania obronne USA i ich sojuszników" (Clinton, 2012). W tym duchu USA już 2008 r. odrzuciły propozycję Rosji i Chin w sprawie zakazu używania broni w kosmosie (PPWT), zarzucając jej brak zakazu posiadania naziemnej broni antysatelitarnej. Ostatecznie w $2012 \mathrm{r}$. USA zadeklarowały, że przyłączą się do prac UE i innych państw nad zmienionym projektem międzynarodowego kodeksu postępowania w przestrzeni kosmicznej.

W 2014 r. powstała już piąta wersja projektu Kodeksu Postępowania (DRAFT International Code of Conduct) poprzedzona trzema rundami konsultacji (w Kijowie, Bangkoku i Luksemburgu) z udziałem 95 państw członkowskich ONZ. Miała służyć lepszemu zrozumieniu stanowisk i obaw wyrażanych przez zainteresowane państwa. Cele wyrażone w najnowszym projekcie Kodeksu praktycznie się nie zmieniły. Należy do nich wzmocnienie ochrony, bezpieczeństwa i trwałości wszelkiej aktywności w przestrzeni kosmicznej dotyczącej zarówno obiektów kosmicznych, jak i środowiska kosmicznego oraz utworzenie „reżimu środków przejrzystości i budowy zaufania”. 
Niestety analiza zmieniającego się na przestrzeni lat języka używanego w kolejnych wersjach Kodeksu ujawnia, że instrument ten ulega sukcesywnemu zmiękczaniu - wyraźnie podkreślony brak obowiązkowego charakteru (Sekcja 1.4), zamiana używanych sformułowań z ,zobowiązać się do" na „postanowić", z „unikać" na „ograniczać”, $\mathrm{z}$,w największym możliwym stopniu” na ,w największym możliwym (wykonalnym) zakresie". Brakuje też jednoznacznego rozróżnienia między bezpieczeństwem a ochroną (wojskową i niewojskową aktywnością w kosmosie). O ile początkowo chwalono całościowy charakter Kodeksu, który miał uwzględniać zarówno wojskowe, jak i cywilne aspekty wykorzystania przestrzeni kosmicznej (bo obecne wyzwania uzasadniają takie podejście), to ostatecznie bezpieczeństwo kosmiczne zyskało wyraźny priorytet w Kodeksie. Widać to zwłaszcza w treści preambuły, w której stwierdza się, że główne zasady, na jakich powinno opierać się całościowe podejście zarówno do bezpieczeństwa kosmicznego, jak i do ochrony kosmosu, to: swoboda dostępu do przestrzeni kosmicznej do celów pokojowych, ochrona bezpieczeństwa i integralności obiektów kosmicznych na orbicie, uwzględnianie słusznej obrony interesów państw. Wszystkie trzy zasady są ściśle związane z bezpieczeństwem kosmicznym, a nie z ochroną kosmosu (Lommelen, 2013, s. 103).

Zasadniczo w wieloletniej debacie nad przygotowanym przez Unię Kodeksem Postępowania dotyczącego Działań w Przestrzeni Kosmicznej zarysowały się dwa główne podejścia: zwolenników i przeciwników twardego lub miękkiego prawa w regulowaniu aktywności kosmicznej. Zwolennicy miękkiego prawa za główną zaletę Kodeksu uznają fakt, że dzięki jego przyjęciu można uniknąć dhugotrwałego procesu negocjacyjnego związanego z wypracowywaniem consensusu niezbędnego do zawarcia wiążącego traktatu. Nie będąc traktatem, Kodeks nie podlegałby też procedurze ratyfikacyjnej, która w wielu przypadkach mogłaby być odwlekana latami. Ponadto żaden prawnie wiążący traktat nie wydaje się obecnie osiagalny $\mathrm{z}$ uwagi na wspomniany wcześniej kryzys w procesie tworzenia prawa kosmicznego na forum ONZ. Co więcej, nieformalne porozumienia niebędące traktatami stanowią zarazem skuteczne środki budowy wzajemnego zaufania między stronami (Meishan, 2008, s. 725-746). Obrońcy Kodeksu od początku podkreślali, że ma on służyć radzeniu sobie z „miękkimi" zagadnieniami, a nie z uzbrajaniem kosmosu. Ewentualne przyjęcie Kodeksu w niczym nie ograniczałoby też dalszych prac nad prawnie wiążącym traktatem, gdy okoliczności ku temu będą bardziej sprzyjające. Istnienie ustalonych reguł postępowania, nawet nieobowiązkowych, pozwala też społeczności międzynarodowej na identyfikowanie podmiotów skłonnych do nieodpowiedzialnego zachowania, i podjęcia stosownej reakcji.

Kodeks jest dokumentem politycznym, a więc zawierającym katalog zasad i najlepszych praktyk (,wzorcowe rozwiązania stosowane wśród podmiotów biorących udział w tych działaniach"), które, jeśli państwa się na nie zgodzą, powinny stać się naturalną częścią sposobów postępowania w przestrzeni kosmicznej. Odróżnia to Kodeks od np. Wytycznych wydanych w 2009 r. przez Komitet ONZ do spraw Pokojowego Wykorzystania Przestrzeni Kosmicznej (Space Debris Mitigation Guidelines). Wytyczne zawierają wskazówki jak należy postępować, aby zmniejszyć ilość kosmicznego gruzu stwarzającego coraz większe zagrożenie dla elementów infrastruktury kosmicznej oraz misji załogowych. Wytyczne mają bardziej techniczny niż polityczny charakter, są bar- 
dziej precyzyjne jako nastawione na sprawdzanie i nadzorowanie stanu środowiska kosmicznego pod kątem krążących w nim odpadów. Odniesienia do Wytycznych, które znalazły się w Kodeksie, mogą pomóc wzmocnić wydźwięk samej idei ograniczania ilości odpadów będących pozostałościami po działaniach człowieka w kosmosie. Niewiążący charakter zarówno Wytycznych, jak i Kodeksu nie oznacza jednak, że ich nieprzestrzeganie nie będzie miało żadnych skutków prawnych - mogą one bowiem wynikać z interpretacji już istniejącego prawa międzynarodowego.

Przeciwnicy Kodeksu jako dokumentu miękkiego prawa wskazują zaś, że z uwagi na jego polityczny charakter nie istnieją ustalone standardy jego interpretowania - inaczej niż w przypadku prawnie wiążących traktatów, które interpretuje się w oparciu o Wiedeńską Konwencję o Prawie Traktatów z 1969 r. Przystępując do traktatu państwa z góry znają i interpretują swoje obowiązki na podstawie Konwencji. Przyjęcie Kodeksu nie daje takiej pewności. Co więcej, Kodeks zezwala na dalsze jego modyfikowanie już po przyjęciu. $Z$ jednej strony może to być zaletą, która będzie zachęcać państwa do jego przyjęcia bez obawy, że później nie będą już miały żadnego wpływu na jego zawartość i stosowanie. $Z$ drugiej jednak strony oznacza to, że nie do końca wiadomo, jaki będzie ostateczny zakres ograniczeń z nim związanych i wynikających z niego korzyści. Niektóre państwa (np. Stany Zjednoczone) widzą w tym zagrożenie dla własnych interesów, ponieważ dopuszczalność zmian mogłaby oznaczać próby nałożenia w przyszłości nieakceptowalnych ograniczeń na ich aktywność i dodanie uciążliwych warunków politycznych, np. uznanie niektórych grup obiektów kosmicznych lub rodzajów działalności (w tym handlowej) za wymagające dalszych regulacji. W ten sposób Kodeks stałby się narzędziem innych państw używanym przeciwko interesom USA (Listner, 2014).

Faktem jest też, że nadal nie istnieją normy zapobiegające możliwości wyścigu zbrojeń w kosmosie. O ile w czasie pokoju miękkie narzędzia mogą wystarczać, ponieważ państwa powstrzymują się od budowy i wykorzystania broni przeciwko kosmicznym aktywom innych, to w razie wzrostu napięcia brak skodyfikowanych norm prawa międzynarodowego w tym zakresie może stwarzać zagrożenie. Dlatego należałoby wzmóc wysiłki na rzecz uzyskania jak najszerszego poparcia dla przyjęcia Kodeksu jako kroku wstępnego do dalszych prac nad zapobieganiem kosmicznemu wyścigowi zbrojeń.

Jednak nie zważając na kluczowe znaczenie zagadnień regulowanych przez Kodeks i rosnących zagrożeń związanych z obecnością gruzu kosmicznego, mocarstwa jak dotąd nie planują podpisać dokumentu, co tłumaczy się głównie chęcią ochrony wojskowej części ich programów kosmicznych. W rezultacie w najbliższych latach przestrzeń kosmiczna nie zostanie poddana ścisłym regułom ani ograniczeniom. Nina Tannenwald wskazuje w związku z tym trzy możliwe scenariusze przyszłego zarządzania przestrzenią kosmiczną: kosmiczna dominacja USA, utrzymanie status quo lub powstanie bardziej rozbudowanego reżimu prawnego obejmującego zarówno traktaty, jak i reguly operacyjne (Tannenwald, 2003, s. 14-15). Zgodnie z pierwszym scenariuszem, Stany Zjednoczone wykorzystując swoją przewagę technologiczną i politykę siły, będą narzucały i egzekwowały korzystne dla siebie reguły dotyczące przestrzeni kosmicznej, lącznie z możliwością rozmieszczania tam broni. W drugim scenariuszu tworzenie zasad odbywa się ad hoc, przyrostowo i fragmentarycznie na podstawie jednostronnych interpretacji ogólnych zasad w połączeniu z nieformalnymi „zasadami 
ruchu drogowego". Trzeci scenariusz zakłada międzynarodową współpracę między wszystkimi podmiotami zainteresowanymi aktywnością w kosmosie oraz rozpraszanie się udziału w procesach decyzyjnych i tworzeniu reguł - na podmioty pozarządowe (zarządzanie policentryczne). Najmniej pożądany (jako niebezpieczny), ale nie najmniej prawdopodobny, jest pierwszy scenariusz. Próby zdominowania przestrzeni kosmicznej przez USA prawdopodobnie zainspirowałyby bowiem inne państwa do podjęcia środków zaradczych skutkujących uruchomieniem wyścigu zbrojeń w kosmosie. Najbardziej pożądany, jako dający trwałe pozytywne rezultaty z perspektywy stabilnego zarządzania przestrzenią kosmiczną, wydaje się trzeci scenariusz - rozwinięty reżim prawny uwzględniający bezpieczeństwo i stabilność wszystkich podmiotów korzystających z przestrzeni kosmicznej. Dlatego Unia Europejska nie ustaje w wysiłkach i nadal pracuje nad przyjęciem Kodeksu. W dniu 9 lutego 2015 r. Rada Unii Europejskiej (WPZiB) przyjęła Decyzję 2015/203 wspierającą propozycję UE odnoszącą się do utworzenia międzynarodowego kodeksu postępowania dotyczącego działań w przestrzeni kosmicznej jako wkładu w środki na rzecz przejrzystości i budowy zaufania w zakresie działań w przestrzeni kosmicznej (Decyzja Rady (WPZiB) 2015/203). Mimo dość powszechnej zgody co do potrzeby powstania kodeksu, to wnioskując na podstawie dotychczasowych stanowisk mocarstw kosmicznych oraz obecnej sytuacji międzynarodowej w najbliższym czasie trudno spodziewać się znaczącego przełomu w pracach nad dokumentem.

\section{Zakończenie}

Rozwijający się międzynarodowy reżim przestrzeni kosmicznej, którego częścią w przyszłości ma szansę stać się Unijny Kodeks dotyczący Działań w Przestrzeni Kosmicznej, potwierdza ogólne przekonanie, że jednym z celów powstawania reżimów międzynarodowych jest ograniczenie egoizmu państw i wspieranie współpracy między nimi. Państwa tworzą zasady i reguły z wielu powodów: ułatwiają one współpracę, pozwalają koordynować działania, stabilizują oczekiwania co do przyszłości, pomagają aktorom zaspokajać interesy i osiagać cele w warunkach współzależności. Jeśli reżim międzynarodowy w jakiejś dziedzinie poprawnie realizuje przypisane mu funkcje wówczas ma duże szanse przetrwania nawet jeśli stosunki między uczestnikami reżimu staną się napięte. Pogorszenie całościowych relacji zwiększa niepewność co do motywacji i przyszłego zachowania innych aktorów, dlatego kooperacja w sferach nie koordynowanych istnieniem reżimu zapewne ustanie lub będzie mocno ograniczona. Jednak w dziedzinach, gdzie istnieją stabilne reżimy zmiana charakteru stosunków nie ma na nie znaczącego wpływu. Reżim kosmiczny ma zapewnić, że przestrzeń kosmiczna pozostanie wolna od konfliktów i nie będzie wykorzystywana przez najbardziej zaawansowane technologicznie państwa wyłącznie we własnym interesie. Unijny Kodeks skupia się na wspólnym 'wrogu', jakim jest kosmiczny gruz, więc tym bardziej państwa powinny połączyć wysiłki, aby móc skuteczniej przeciwstawić się zagrożeniom, jakie niesie ze sobą jego obecność. Jest to szczególnie istotne dla zapewnienia niezakłóconego korzystania z infrastruktury kosmicznej, kluczowego m.in. z punktu widzenia bezpieczeństwa narodowego i międzynarodowego. Choć kodeks postępowa- 
nia jest dobrowolny i niewiążący, akceptacja państw kosmicznych jest ważna, a brak udziału niektórych mocarstw znacząco ograniczyłby jego znaczenie i wpływ. Nie jest prawda, że to słabe państwa są bardziej skłonne do polegania na regułach, bo reguły ograniczają władzę silnych. W rzeczywistości nawet najsilniejsze państwa odnoszą (i doceniaja) korzyści płynące zarówno z „miękkiej”, jak i „twardej” potęgi tkwiącej w zasadach i dlatego wspierają zasady służące ich interesom (Ikenberry, Kupchan, 1990, s. 283-315). Pozwala to lepiej zrozumieć niektóre trudności związane z wypracowaniem międzynarodowego kodeksu. Jednak niezależnie od ostatecznego wyniku prac nad dokumentem, już sam proces negocjacyjny podnosi świadomość potrzeby kooperatywnego podejścia do zarządzania przestrzenią kosmiczną i ustalenia katalogu praktyk zachowań w kosmosie.

\section{Bibliografia}

Agreement Governing the Activities of States on the Moon and Other Celestial Bodies (Moon Agreement), http://www.islandone.org/Treaties/BH766.html, 3.01.2011.

Bernardsdotter E. (2013), The EU and Star Wars: The Space Code of Conduct as a Tool for Security Policy, w: Strategic Outlook 2013, eds. M. T. Lindell, J. Hellstrom, L. Molin, A. Wiss, Swedish Defence Research Agency, Stockholm, http://www.foi.se/ReportFiles/foir_3682.pdf, 15.10.2014.

Black J. (2008), Constructing and Contesting Legitimacy and Accountability in Polycentric Regulatory Regimes, 2 Regulation \& Governance 2.

Blount P. J. (2012), Targeting in Outer Space: Legal Aspects of Operational Military Actions in Space, „Harvard National Security Journal”, http://harvardnsj.org.

Bryla J. (2006), Rozwój i znaczenie reżimów międzynarodowych na przykladzie reżimu nieprolıferacji broni jadrowej, Wydawnictwo Naukowe SCHOLAR.

Bryła J. (2013), Bezpieczeństwo państwa w świetle teorii dóbr publicznych, „Przegląd Strategiczny”, nr 1 , s. $13-38$.

Bryla J. (2015), Delimitacja przestrzeni kosmicznej: cel, zasadność, rywalizacja interesów, „Prace i Studia Geograficzne. Geografia Polityczna”, red. naukowa M. W. Solarz, M. Wojtaszczyk. Wydział Geografii i Studiów Regionalnych, s. 8-9.

Buck S. J. (2012), The Global Commons: An Introduction, Island Press, Washington, D.C.

Buck S. J. (2013), Understanding Environmental Administration and Law, Island Press, Washington, D.C.

Clinton H. (2012), International Code of Conduct for Outer Space Activities, Press Release US Department of State, www.state.gov/secretary/rm/2012/01/180969.htm, 19.06.2014.

Conclusions of the Council of the European Union no. 14455/10, on the revised draft Code of Conduct for outer space activities, 11 October 2010, https://www.consilium.europa.eu/uedocs/cmsUpload/st14455.en10.pdf, 26.10.2011 [tekst w j. polskim: Zmieniony Projekt, Kodeks Postępowania dotyczacy Dzialań w Przestrzeni Kosmicznej (2010), http://data.consilium .europa.eu/ doc/document/ST-14455-2010-INIT/pl/pdf, 8.03.2014].

Decyzja Rady (WPZiB) 2015/203 z dnia 9 lutego 2015 r. wspierajaca propozycję Unii odnoszacq sie do międzynarodowego kodeksu postępowania dotyczqcego dziatań w przestrzeni kosmicznej jako wkladu w środki na rzecz przejrzystości i budowy zaufania w zakresie dzialań $w$ prze- 
strzeni kosmicznej, eur-lex.europa.eu/legal-content/PL/TXT/PDF/?uri=CELEX:32015D0203 $\&$ from $=$ PL, 30.03.2015.

Dolman E. C. (2002), Astropolitik: Classical Geopolitics in the Space Age, Frank Cass, London.

DRAFT International Code of Conduct for Outer Space Activities, 31 March 2014, http://www.eeas.europa.eu/non-proliferation-and-disarmament/pdf/space_code_conduct_draft vers_31-march-2014_en.pdf, 29.01.2015.

Einstein E. J. (1999), Owning Outer Space, „Northwestern Journal of International Law \& Business”, vol. 20, Issue 1 Fall.

Global governance and governance of the global commons in the global partnership for development beyond 2015, UN System Task Team on the Post-2015 UN Development Agenda, January 2013, http://www.un.org/en/development/desa/policy/untaskteam_undf/thinkpieces/24_thinkpiece_global_governance.pdf, 17.05.2014.

Goldman M. (2013), Prywatyzacja przyrody i „odkrycie” dóbr wspólnych, „Ekologia Polityczna - Biblioteka Online". http://www.ekologiasztuka.pl/pdf/ep005 goldman_2013.pdf, 5.01.2015.

Haas E. B. (1990), When knowledge is power Three Models of Change in International Organizations, University of California Press, California.

Hacket G. (1994), Space debris and the Corpus Iuris Spatialis, Editions Frontières, Paris.

Hardin G. $(1968,1992)$, The Tragedy of the Commons, „Science” 162 (3859), http://www.sciencemag.org/cgi/content/full/162/3859/1243, 2.11.2012.

Hasenclever A., Mayer P., Rittberger V. (1996), Interests, Power, Knowledge: The Study of International Regimes, „Mershon International Studies Review”, nr 40.

Hasenclever A., Mayer P., Rittberger V. (1997), Theories of International Regimes, Cambridge University Press, Cambridge, http://eur-lex.europa.eu/legal-content/PL/TXT/PDF/?uri=CELEX:32015D0203\&from=PL, 30.03.2015.

Ikenberry J., Kupchan Ch. (1990), Socialization and Hegemonic Power, „International Organization”, vol. 44 (Summer), s. 283-315.

Interim Agreement Between the United States of America and the Union of Soviet Socialist Republics on Certain Measures with Respect to the Limitation of Strategic Offensive Arms (SALT I). http://cns.miis.edu/inventory/pdfs/aptsaltI.pdf, 13.12.2014.

International Task Force on Global Public Goods, http://www.gpgtaskforce.org/bazment.aspx?page_id=147, 29.01.2012.

Jaramillo C. (2011), Limited rules of engagement: Even if the Code of Conduct for Outer Space Activities is adopted, a significant void will remain, „The Ploughshares Monitor”, Winter, vol. 32. Issue 4, http://ploughshares.ca/pl_publications/limited-rules-of-engagement-even-if-the-code-of-conduct-for-outer-space-activities-is-adopted-a-significant-void-will-remain/, 12.12.2012.

Kaul I., Grunberg I., Stern M. A. (eds.) (1999), Global Public Goods: International Cooperation in the $21^{\text {st }}$ Century, Oxford University Press, New York.

Keohane R. O., Nye J. S. (1977), Power and Interdependence, Little Brown, Boston-Toronto.

Keohane R. O., Nye J. S. (1987), Power and Interdependence Revisited, „International Organization”, vol. 41, nr 4, Autumn, s. 725-753.

Keohane R. O., Victor D. G. (2010), The Regime Complex for Climate Change 10, Harvard Kennedy School ed., January, Discussion Paper 10-33, http://belfercenter.ksg.harvard.edu/files/Keohane_Victor_Final_2.pdf, 24.05.2013.

Konwencja o międzynarodowej odpowiedzialności za szkody wyrzadzone przez obiekty kosmiczne. sporządzona w Moskwie, Londynie i Waszyngtonie dnia 29 marca 1972 r., Dz. U. 1973, Nr 27. poz. 154 [Dz. U. 73.27.154], http://www.dziennikustaw.gov.p1/du/1973/s/27/154/1, 11.11.2013. 
Konwencja o przekazywaniu i wykorzystywaniu danych ze zdalnego badania Ziemi z kosmosu z 1978 roku, Dz. U. 1980, Nr 10, poz. 27 - zalącznik, http://www.prawo.pl/dz-u-akt/-/dokument/Dz.U.1980.10.27/16790506/24498.

Konwencja o rejestracji obiektów wypuszczonych w przestrzeń kosmiczna, otwarta do podpisania w Nowym Jorku dnia 14 stycznia 1975 r., Dz. U. 1979, Nr 5, poz. 22, http:/www.dokumenty.rcl.gov.pl/DU/rok/1979/wydanie/5/pozycja/22, 17.10.2013.

Krasner S. D. (1983), Structural causes and regime consequences:regimes as intervening variables. w: International Regimes, ed. S. D. Krasner, Cornell, Ithaca-New York.

Laver M. (1986), Public, Private and Common in Outer Space: Res Extra Commercium or Res Communis Humanitatis Beyond the High Frontier?, „Political Studies”, XXXIV.

Levy M. A., Young O. R., Zürn M. (1995), The Study of International Regimes, „European Journal of International Relations", $\mathrm{nr} 1$ (3).

Listner M. (2014), Commentary. U.S. Should Take a Cold, Hard Look at Space Code of Conduct. http://spacenews.com/40128us-should-take-a-cold-hard-look-at-space-code-of-conduct/: 29.09 .2014

Lommelen J., International Code of Conduct for Sustainable Activities in Outer Space. www.lib.ugent.be/fulltxt/RUG01/.../RUG01-002060925_2013_0001_AC.pdf, 27.02.2014.

Lukaszczyk A. (2012), International Code of Conduct for Outer Space Activities vis a vis other space security initiatives, http://swfound.org/media/93074/iac_2012__icoc_al.pdf, 8.09.2014.

March J. G., Olsen J. P. (2005), Instytucje. Organizacyjne podstawy polityki, Wydawnictwo Naukowe SCHOLAR, Warszawa.

Mason N. C. (2004), Forging a New Global Commons. Introducing common property into the global genetic resource debate, University of Canterbury, http://ir.canterbury.ac.nz/bitstream/10092/904/1/thesis_fulltext.pdf, 18.01.2012.

McDougal M. S. (1963), The Emerging Customary Law of Space, Faculty Scholarship Series, Paper 2609, http:/digitalcommons.law.yale.edu/fss_papers/2609, 20.03.2010.

Meishan Goh G. (2008), Softly, softly Catchee monkey: informalism and the quiet development of international space law, „Nebraska Law Review”, vol. 87, Issue 3.

Milner H. (1993), International Regimes in World Politics: Comments on the Articles by Smouts, de Senarclens and Jonsson, „International Social Sciense Journal”, nr 45 (4).

Model Code Of Conduct, 2013, Stimson Center, http://www.stimson.org/research-pages/model-code-of-conduct/, 29.11.2014.

Nevers de R. (1999), Regimes as Mechanisms for Global Governance, Rockefeller Brothers Fund. New York.

Ozgercin K. V., Weiss Th. G. (2009), The Evolution of Global Governance: Theory and Practice, „International Relations", vol. II, eds. J. Wiener, R. A. Schrire, The State University of New York, College at Old Westbury, s. 137-155.

Orsini A., Morin J.-F., Young O. (2013), Regime Complexes: A Buzz, a Boom, or a Boost for Global Governance?, „Global Governance” 19, s. 27-39.

Ostrom E. (2008), Polycentric Systems as One Approach for Solving Collective-Action Problems 2-3, Indiana University Workshop in Political Theory and Policy Analysis, Working Paper Series $\mathrm{nr}$ 08-6, http://dlc.dlib.indiana.edu/dlc/bitstream/handle/10535/4417/W08-6_Ostrom_DLC.pdf, 2.03.2012.

Ostrom E. (2010), Polycentric Systems for Coping with Collective Action and Global Environmental Change, 20 Global Environmental Change 20.

Padget S. A. (1996), Issues in space law and policy [online] Monterey, Naval Postgraduate School, California, http://hdl.handle.net/10945/8587, 30.01.2015. 
Puchala D. J., Hopkins R. F. (1982), International regimes: lessons from inductive analysis, „International Organization" 36, $\mathrm{nr}$ 2, Spring.

Regional Perspectives on Norms of Behaviour for Outer Space Activities (2015), UNIDIR/2015/1, New York-Geneva, http://www.unidir.org/files/publications/pdfs/regional-perspectives-on-norms-of-behaviour-for-outer-space-activities-en-622.pdf, 28.03 .2015$.

Robinson J. (2012), Europe's Space Diplomacy Initiative: The International Code of Conduct, w: A. Lele, Decoding the International Code of Conduct for Outer Space Activities, Pentagon Security International, New Delhi.

Robinson J. (2013), Space Crisis Management: Europe's Response, European Space Policy Institute Report 44, February, http:/www.mercury.ethz.ch/.../Files/.../ESPI_Report_44.pdf, 22.04.2014.

Shackelford S. J. (2014), Governing the Final Frontier: A Polycentric Approach to Managing Space Weaponization and Debris, „American Business Law Journal”, vol. 51, Issue 2, Spring.

Space Debris Mitigation Guidelines (2009), http://orbitaldebris.jsc.nasa.gov/library/Space\%20Debris $\% 20$ Mitigation $\% 20$ Guidelines_COPUOS.pdf, 3.11.2014.

Su J., Lixin Z. (2014), The European Union draft Code of Conduct for outer space activities: An appraisal, „Space Policy”, http://dx.doi.org/10.1016/j.spacepol.2014.01.002, 7.12.2014.

Tannenwald N. (2003), Law Versus Power on the High Frontier: The Case for a Rule-Based Regime for Outer Space, Watson Institute for International Studies, Brown University, April.

Transparency and Confidence-Building Measures in Outer Space Activities (2013), Study Series 34. Office for Disarmament Affairs, United Nations, New York, http://www.un.org/disarmament/publications/studyseries/en/SS-34.pdf, 29.01.2014.

Treaty Between the United States of America and the Union of Soviet Socialist Republics on the Limitation of Strategic Offensive Arms, Together With Agreed Statements and Common Understandings Regarding the Treaty (SALT II), http://cns.miis.edu/mventory/pdfs/aptsaltII.pdf. 13.12.2014.

Uktad o zasadach dziatalności państw w zakresie badań i użtkowania przestrzeni kosmicznej, tacznie z Księżycem i innymi ciatami niebieskimi", Dz. U. 1968, Załącznik nr 2 do Nr-u 14, poz. 82 z dnia 15 maja 1968 r. [Dz. U. 68.14.82], http://www.dziennikustaw.gov.pl/du/1968/s/14/ 82/D1968014008202.pdf, 11.11.2013.

UNCOPUOS, http://www.unoosa.org/oosa/COPUOS/cop_overview.html.

Vlasic I. A. (1991), The Legal Aspects of Peaceful and Non-Peaceful Uses of Outer Space, w: Peaceful and Non-Peaceful Uses of Space; Problems of Definition for the Prevention of an Arms Race", ed. B. Jasani, Taylor\&Francis, New York.

Vogler J. (1995), The Global Commons, John Wiley \& Sons, Toronto.

Young O. R. (1982), Regime dynamics: the rise and fall of international regimes, „International Organization", vol. 36 , $\mathrm{nr} 2$, Spring.

\section{Streszczenie}

Rosnące uzależnienie państw i społeczeństw od wykorzystania technologii kosmicznych skutkuje nasilającą się aktywnością w przestrzeni kosmicznej prowadzoną też przez nowe podmioty, zarówno państwowe, jak i niepaństwowe. Generuje to wiele negatywnych skutków czyniących środowisko kosmiczne coraz mniej bezpiecznym miejscem (np. gruz kosmiczny). Pojawiające się zagrożenia mogą mieć wpływ na bezpieczeństwo narodowe i międzynarodowe na ziemi. W efekcie narasta pilna potrzeba kolektywnego podejścia do zarządzania korzysta- 
niem z przestrzeni kosmicznej. Rozwijający się od początku ery kosmicznej międzynarodowy reżim prawny dotyczący tego środowiska nie jest już wystarczający, gdyż nie uwzględnia w wystarczającym stopniu szybko zachodzących zmian. Jedną z prób przezwyciężenia tego problemu jest przygotowany przez Unię Europejską w 2008 r. projekt międzynarodowego Kodeksu Postępowania dotyczący Działań w Przestrzeni Kosmicznej. Artykuł wskazuje ważniejsze przyczyny, dla których, mimo wieloletnich wysiłków i narastających problemów, nadal nie znalazł on akceptacji mocarstw niezbędnej, by stać się ważnym elementem międzynarodowego reżimu kosmicznego.

Słowa kluczowe: reżimy międzynarodowe, globalne wspólne dobra, międzynarodowy reżim kosmiczny, Kodeks Postępowania dotyczący Działań w Przestrzeni Kosmicznej, bezpieczeństwo kosmiczne

\section{The contribution of the European Union to the advancement of the international space regime}

\section{Summary}

The growing dependence of countries and societies on the use of space technologies results in the increasing activity in outer space of new actors, both state and non-state. It produces a number of adverse outcomes for the space environment, making it a less and less safe place (e.g. space debris). Emerging threats may affect national and international security on earth. As a result, an urgent need for a collective approach to the management of the use of outer space is emerging. The international legal regime for outer space that has been developing since the beginning of the space age is no longer sufficient, because it does not take into account many rapid changes. One of the attempts to overcome this problem is the International Code of Conduct for Outer Space Activities drafted by the European Union in 2008. This paper discusses the reasons why, despite long-lasting efforts and intensifying problems, the Code has so far failed to win the approval of the powers which is requisite to constitute an important part of the international outer space regime.

Key words: international regimes, global common goods, international space regime, Code of Conduct for Outer Space Activities, space security 